UDC 343.123.12(4-672EU) ; 343.85(4-672EU)

CERIF: S155

\author{
Maja Lukić, PhD, LLM ${ }^{*}$
}

\title{
THE NEW THEATRE OF THE STRUGGLE FOR EU UNITY - JUDICIAL COOPERATION IN CRIMINAL MATTERS AND POLICE COOPERATION CONFRONTS MEMBER STATE SOVEREIGNTY
}

\begin{abstract}
Most institutions that play crucial role in enforcement of EU law regulating judicial cooperation in criminal matters and police cooperation today had existed before the enactment of the Lisbon Treaty, which transformed the nature of European legislation in that area from intergovernmental to supranational. The Lisbon Treaty afforded judicial cooperation in criminal matters and police cooperation a pronounced idiosyncrasy: the greatest degree of flexibility of Member State participation. The experience gained in applying the mechanism of enhanced cooperation, including the concept of the European public order, contributes to the utility of the entire body of law on judicial cooperation in criminal matters and police cooperation as the new unifying factor of the EU.
\end{abstract}

Key words: $\quad$ Area of Freedom. - Security and Justice. - European public order. - Enhanced Cooperation. - Lisbon Treaty.

\section{INTRODUCTION}

The integration of the European Union has resulted seemingly more from the developments of the EU law, particularly from the case-law of the Court of Justice of the European Union (CJEU), than from a political process. ${ }^{1}$ In the course of the past five decades several areas of law have ius.bg.ac.rs

* Assistant Professor at the University of Belgrade Faculty of Law, maja.lukic@

1 Cappelletti, Seccombe and Weiler developed a theoretic framework on the basis of this phenomenon, which to a fair extent remained useful for understanding the develop- 
appeared on the forefront of EU integration. Certain recent events suggest that judicial cooperation in criminal matters and police cooperation may have become the new engine for furthering the unity of the EU.

\section{KEY ACHIEVEMENTS PRECEDING LISBON}

Before Lisbon Treaty, justice and home affairs belonged to the socalled third pillar, and the CJEU lacked jurisdiction over that field. ${ }^{2}$ In that period, judicial cooperation in criminal matters and police cooperation relied on instruments of a predominantly intergovernmental nature, and it continues to rely on some of the major instruments from that period. ${ }^{3}$ These are mostly framework decisions, which were not accorded direct effect. ${ }^{4}$ Among these, two have been regarded as the most important - those providing for the European Arrest Warrant (EAW), ${ }^{5}$ and the European Evidence Warrant (EEW). ${ }^{6}$ The former has drawn until present by

ments that succeeded the publishing of their work. See: M. Cappelletti, M. Seccombe, J. H. Weiler (eds.) Integration Through Law - Europe and the American Federal Experience, Walter de Gruyter, Berlin - New York 1986, 1-5.

2 As summarised by Brkan, until Amsterdam Treaty of 1997, the Member States could only adopt conventions by virtue of which jurisdiction would be bestowed upon the CJEU in the subject field; the Amsterdam Treaty (Art. K7(2)) introduced the possibility that the CJEU issues preliminary rulings, but only when a Member State accepts such jurisdiction. M. Brkan, "The Role of the European Court of Justice from Maastricht to Lisbon: Putting together the scattered pieces of patchwork", The Treaty on European Union 1993-2013: Reflections from Maastricht (eds. M. de Visser, A. Pieter van der Mei), Intersentia, Cambridge-Antwerp-Portland 2013, 90.

3 Protocol (No. 36) on Transitional Provisions, Article 9, Official Journal of the $E U$, C326, 26. 10. 2012. See also: Wolfgang Bogensberg, Rudi Troosters, "The End of Soft Law Cooperation: the Court's Jurisprudence in Criminal Matters", International Review of Penal Law 1/2006, 334-345.

4 As noted by Dane and Goudappel, Member States adopted national measures in view of the fact that framework decisions did not have direct effect. The Lisbon Treaty cancelled such differentiation of framework decisions vis-à-vis ordinary decisions, whereas CJEU gained full jurisdicton in respect of measures based on the legislation in the Area of Freedom, Security and Justice as of 1 December 2014. The result of the two occurences may be that certain national measures will have to be renegotiated. M. Dane, F. Goudappel, "European Criminal Law", Freedom, Security and Justice after Lisbon and Stockholm (eds. S. Wolff, F. Goudappel, J. de Zwaan), TMC Asser Press, The Hague 2011, 156.

5 Council framework decision of 13 June 2002 on the European Arrest Warrant and the surrender procedures between Member States - Statements made by certain Member States on the adoption of the Framework Decision, 2002/584/JHA, Official Journal L 190, 18/07/2002, $0001-0020$.

6 Framework decision 2008/978/JHA on the European Evidence Warrant, OJ L 350/72, 30 December 2008, COM(2003)688. 
far the greatest number of controversies both in academia and in courts, especially before national constitutional courts. ${ }^{7}$

Several years before enactment of the Lisbon Treaty, judicial cooperation in criminal matters started evolving from a system based on mutual legal assistance to one based on mutual recognition. The principal driver of that evolution was the European Arrest Warrant. Framework decisions were the instrument of choice also for a limited harmonization of substantive criminal law in the decade preceding enactment of the Lisbon Treaty. ${ }^{8}$ In that period, the CJEU also made its contribution to the creation of a limited body of substantive criminal EU law by resorting to the doctrine of implied Union powers - by virtues of two decisions of 2005 and 2007 it upheld two decisions of the Council, enacted under the Third Pillar, whereby Member States were required to prescribe criminal penalties for certain environmental offences. In essence, the Court opined that criminalization was justified if it had been effective, proportionate and necessary for enforcement of environmental protection.

Most institutions that play a crucial role in enforcement of judicial cooperation in criminal matters and police cooperation within the presentday EU had been in existence before enactment of the Lisbon Treaty: Europol, Eurojust, OLAF, and Frontex.

\section{NOVELTIES BROUGHT BY LISBON TREATY AND STATE OF PLAY}

The Lisbon Treaty brought significant changes - the judicial cooperation in criminal matters and police cooperation were removed from the former third pillar, which was thus abolished, into the Area of Freedom, Security and Justice, ${ }^{10}$ forming part of the equivalent of the former first pillar. ${ }^{11}$ The coming into effect of these changes was postponed until 1 December 2014, at which point the CJEU gained its normal jurisdiction

7 Damian Chalmers, Gareth Davies, Giorgio Monti, European Union Law, Cambridge University Press, Cambridge 20153, 642; See: Libor Klimek, European Arrest Warrant, Springer, Cham - Heidelberg 2015.

8 For a concise outline of these instruments see M. Dane, F. Goudappel, 159.

9 Case C-176/03, Commission v. Council (Environmental Crime), ECR I-7879, European Court of Justice, 13 September 2005 and Case C-440/05, Commission v. Council (Ship-source Pollution), ECR I-9097, European Court of Justice, 23 October 2007.

10 Marković points out that the Area of Freedom, Security and Justice is enumerated in Art. 3 of the UEU both before the European Internal Market and the European Monetary Union, as well as that such order of enumeration is indicative of Union's evolution beyond economic goals. I. Marković, "Evropsko krivično pravo", Pravni život 12/2012, 507 .

11 See: I. Marković, “Evropsko krivično pravo”, Pravni život 12/2012, 503-520. 
in that field as well. Among the reasons proposed by Peers for the significance of that date for judicial cooperation in criminal matters and police cooperation, we stress the fact that the EU Commission became empowered to bring infringement actions against Member States which had not implemented pre-Lisbon EU criminal law measures, or did so improperly. A number of measures may become grounds for such infringement proceedings: transfer of prisoners, probation, parole and supervision orders, hate crimes and Holocaust denial, conflicts of jurisdiction and recognition of prior convictions. ${ }^{12}$ All the measures enacted under the previous third pillar are now treated as all other EU legislative measures from the perspective of CJEU powers. ${ }^{13}$

The Lisbon Treaty has accorded the system of mutual recognition an important role in respect of judicial cooperation in criminal matters, but at the same time provided for direct harmonization of certain areas of criminal procedural law - rights, support and protection of victims of crime ${ }^{14}$ the right to continue to benefit from protection measures when moving to another Member State. ${ }^{15}$ From the fact that the directive on victims' rights does not stipulate a right to compensation, some authors deduce that its central role is "to patrol the investigative process and criminal proceedings". ${ }^{16}$ In the post-Lisbon environment, the Commission has been proposing separate pieces of legislation for individual procedural rights, thus compensating for the unsuccessful proposal for a framework directive of 2004. In 2013 the Commission proposed a package of decisions relating to the presumption of innocence and the right to be present at trial, special safeguards for children suspected and accused in criminal proceedings, and provisional legal aid was proposed. ${ }^{17}$

An avenue for creating a body of substantive criminal norms at the level of EU law has been introduced by virtue of TFEU Art. 83 (1) and

12 S. Peers, "Childhood's End: EU Criminal Law in 2014", EU Law Analysis 29. 12. 2014. http://eulawanalysis.blogspot.com/2014/12/childhoods-end-eu-criminal-law-in2014.html, last visited 15 October 2015.

13 E. Capitani, "Metamorphosis of the third pillar: The end of the transition period for EU criminal and policing law", EU Law Analysis 10. 7. 2014, http://eulawanalysis. blogspot.co.uk/2014/07/metamorphosis-of-third-pillar-end-of.html, last visited 5 October 2015.

14 Directive 2012/29/EU of the European Parliament and of the Council of 25 October 2012 establishing minimum standards on the rights, support and protection of victims of crime, and replacing Council Framework Decision 2001/220/JHA, OJ L 315, 14.11.2012, 57-73.

15 Directive 2011/99/EU of the European Parliament and of the Council of 13 December 2011 on the European protection order, OJ L 338, 21.12.2011, 2-18.

16 D. Chalmers, G. Davies, G. Monti, 625.

17 The European Commission, Criminal Justice, Rights of suspect and accused, http://ec.europa.eu/justice/criminal/criminal-rights/index_en.htm, last visited 15 October 2015. 
(2): for the purpose of establishing "minimum rules concerning the definition of criminal offences and sanctions in the areas of particularly serious crimes with a cross-border dimension, resulting from the nature or impact of such offenses of from a special need to combat them on a common basis", in accordance with ordinary legislative procedure, and "if the approximation of criminal laws and regulations of the Members States proves essential to ensure the effective implementation of a Union policy in an area which has been subject to harmonisation measures", in accordance with procedure applicable to the underlying harmonisation measure.

Claiming that a codification of the general part of EU criminal law is indispensable in case the EU wishes to directly enforce its criminal law, Klip has pointed out that the existing treaty basis is sufficient for the EU to legislate the general part of EU criminal law, as well as that it has already implicitly done so in relation to certain criminal offences. ${ }^{18}$

Chalmers, Davies and Monti emphasize that the idiosyncrasy of that area of law persists despite the fact that it has become like any other area of EU law by virtue of the Lisbon Treaty, and attribute such persistence to strong nexus between criminal law and national sovereignty, as well as due to deep-rooted tradition of intergovernmental legislative activity in that field. ${ }^{19}$ These authors have recognized three points at which TFEU affords special treatment to this field. ${ }^{20}$ Firstly, in the fields of judicial cooperation in criminal matters and police cooperation the Commission shares the right of legislative initiative with one quarter of Member States. ${ }^{21}$ If legislative initiative is taken by the Member States, then TFEU Art. 295(15) deprives the Commission of the option to provoke the requirement of unanimity in the Council by giving a negative opinion in the second reading. Secondly, an "emergency brake procedure" is available to Member States in respect of legislative proposals that purport to create substantive criminal norms at the EU level. The mechanism allows any Member State to refer a draft measure to the European Council, which must accept it by unanimity. This procedure, however, is balanced with automatic approval of enhanced cooperation in such a situation, for initiatives submitted by at least nine Member States. ${ }^{22}$ A lower threshold for the number of votes of national parliaments claiming non-compliance of a draft legislative act with the principle of subsidiarity is prescribed

18 A. Klip, "Towards a General Part of Criminal Law for the European Union", Substantive Criminal Law of the European Union (ed. A. Klip), Maklu, Antwerpen Apeldoorn 2011, 19, 24-25, 32.

19 D. Chalmers, G. Davies, G. Monti, 626.

20 Ibid., 635-636.

21 TFEU Art. 76.

22 TFEU Art. 83(3). 
solely for this area of EU law: one fourth instead of one third for all other situations. ${ }^{23}$ Finally, the Lisbon Treaty accorded to the United Kingdom the right to opt-out, in the field of police cooperation and criminal law, of both the pre-Lisbon measures, and of those enacted after entry into force of the Lisbon Treaty, as well as to re-enter some of the measures. The UK exercised the block opt-out in 2013, after which it has been allowed to re-enter to a number of pre-Lisbon measures. ${ }^{24}$ De Witte predicts that the phenomenon to which he refers as to "variable geometry" of the EU, consisting in a number of mechanisms ensuring institutional flexibility, is "likely to last, and to flourish". ${ }^{25}$

As has already been noted, pre-Lisbon intergovernmental measures continue to produce legal effects in the post-Lisbon, mostly supranational, environment. Peers has pointed to two recent CJEU judgments, ${ }^{26}$ which in effect authorize the Council to adopt the implementing measures to pre-Lisbon acts by following the pre-Lisbon rules. ${ }^{27}$ The significance of this authorization lies in the fact that pre-Lisbon measures mostly do not have direct effect, and thus do not create individual rights that can be invoked before national courts, as well as in the fact that the European Parliament does not have legislative competence in respect of such measures.

It was only by virtue of the Lisbon Treaty (Article 86) that the grounds for establishment of the Office of the European Public Prosecutor (EPPO) have been set forth. The prosecutor would be responsible for investigating, prosecuting and bringing to judgment the perpetrators of, and accomplices in, offences against the financial interests of the Union. Such designation of competence corresponds to the scope of investigative powers of the OLAF. Unlike OLAF, which has been operating since 1999, the office of the European Public Prosecutor is still in the making. ${ }^{28} \mathrm{At}$

23 Protocol (No. 2) on the Application of the Principles of Subsidiarity and Proportionality, Art. 7 (2), OJ of the European Union, C236, 26. 10. 2012, 7.

24 De Witte based his prediction not only on the analysis of institutional mechanisms available under primary legislation, but also on the examples of the European Monetary Union and the Fiscal Compact. Bruno de Witte, "Five Years After the Lisbon Treaty's Entry into Force: Variable Geometry Running Wild?", Editorial, Maastricht Journal of European and Comparative Law 1/2015, 3-9.

25 De Witte, 9.

26 Judgment of the Court (Fourth Chamber) of 16 April 2015, C-540/13, European Parliament v. Council of the European Union, and Judgment of the Court (Fourth Chamber) of 16 April 2015, European Parliament v. Council of the European Union, Joined Cases C-317/13 and C-679/13.

27 S. Peers, "EU Zombie Law: the CJEU re-animates the old 'third pillar"”, EU Law Analysis, 17 April 2015, http://eulawanalysis.blogspot.com/2015/04/eu-zombie-lawcjeu-re-animates-old.html, last visited 15 October 2015.

28 This paper has been drafted as of, and thus all statements referring to present time refer to 1 November 2015. 
present, the Commission's proposal for the regulation on the establishment of that office is undergoing discussions within the Council and its preparatory bodies ${ }^{29}$ That proposal is coordinated with the Commission's proposal for reform of Eurojust, aimed at ensuring support of Eurojust to EPPO, involvement of the European Parliament and of the national parliaments in evaluation of Eurojust's performance, and differentiating between Eurojust's operational and administrative functions. ${ }^{30}$ The treaty basis for EPPO reveals at the same time the importance accorded to that office by the framers of the Lisbon Treaty, and their awareness that establishment of EPPO may not be accepted unanimously - TFEU Art. 86(1) prescribes a special procedure of enhanced cooperation, which in effect provides for automatic authorization of enhanced cooperation if at least nine Member States request it, and upon failure of both the Council and the European Council to reach unanimity on the matter. TFEU Art. 86(4) allows the European Council, acting unanimously upon obtaining consent of the European Parliament and consulting the Commission, to extend the powers of EPPO to "serious crime having a cross-border dimension." The crucial points in the ongoing debate about EPPO consist in the choices for the levels - EU or national - at which ex-ante authorization of coercive measures and decisions on remedies against certain judicial decisions, including the choice of jurisdiction, shall be made. ${ }^{31}$

\section{ENHANCED COOPERATION}

Enhanced cooperation is a treaty-based mechanism that enables at least nine Member States to enact measures within the Union's non-exclusive competences. It is associated with concepts of asymmetric integration, "constitutional variable geometry", and "the multi-speed Europe". In contrast to the seemingly fragmentizing nature of the mechanism, TEU proclaims that enhanced cooperation "shall aim to further the objectives of the Union protect its interests and reinforce its integration process."32

The Lisbon Treaty introduced three different procedures for establishing enhanced cooperation: the default procedure, the procedure ap-

29 For the state of legislative proceedings and the text of the proposal see EURLex, Procedure 2013/0255/APP, http://eur-lex.europa.eu/legal-content/EN/HIS/? uri=celex: 52013PC0534, last visited 15 October 2015.

30 European Commission, Proposal for a Regulation of the European Parliament and of the Council on the European Union Agency for Criminal Justice Cooperation (Eurojust), COM (2013) 535 final, 2013/0256 (COD), Brussels, 17.7.2013, http://eur-lex.europa.eu/legal-content/EN/TXT/PDF/? uri $=C E L E X: 52013 P C 0535 \&$ from $=E N$, last visited 15 October 2015.

31 J. Vervaele, "Guest Editorial", Eucrim 2/2014, 45-46; A. Klip, European Criminal Law: An Integrative Approach, 459-464.

32 TEU Art. 21(1). 
plicable in the area of Common Foreign and Security Policy (CFSP), and the one applicable in the area of criminal and police matters.

The first two are stipulated in TEU Art. 20 and in TFEU Art. 326334 - while the default procedure depends on the Commission's willingness to submit a proposal to the Council, as well as on the approval of the European Parliament, the procedure applicable in relation to CFSP requires only that opinions be obtained from the High Representative for Foreign Affairs and Security Policy and the Commission, so that the request is approved by the Council, by unanimity of representatives of the participating Member States. Cremona explains the greater flexibility afforded to enhanced cooperation in the area of CFSP as a result of the fact that the operational flexibility in the area of common defense and security policy proved highly practical before Lisbon, due to Member States varying international defense commitments and operational capacities. ${ }^{33}$

Enhanced cooperation in the areas of judicial cooperation in criminal matters and police cooperation has been afforded an even greater flexibility than the one in the area of CFSP, by virtue of a number of special identical provisions of TFEU ${ }^{34}$ - enhanced cooperation is established merely by virtue of a notification addressed to the European Parliament, the Council and the Commission, whereas consent of the Commission and of the Council is deemed granted, furthermore, participating Member States do not need to show that their proposal represents a means of last resort. The enhanced procedure mechanism in the area of criminal matters (apart from the clause on EPPO) is in one particular instance related to another idiosyncrasy of the decision-making process in that area - the so-called "emergency brake" mechanism, afforded to all Member States in relation to legislative proposals for creation of substantive criminal norms at the EU level. This most flexible variety of enhanced cooperation, thus, counterbalances the emergency brake, but has a much wider field of application, and is often referred to as the "accelerator clause". ${ }^{35}$

Herlin-Karnell noted that the absence of obligation to show the last resort character of enhanced cooperation in the area of criminal law contravenes the sensitive nature of that area of law, that such great flexibility in establishing enhanced cooperation in the subject area increases the risk of varying degrees and notions of freedom, security and justice, as well as that it deprives the European Parliament of a legislative role. ${ }^{36}$

33 M. Cremona, "Enhanced cooperation and the common foreign and security and defense policies of the EU", EUI Working Papers, Law 2009/21, 11, 15.

34 TFEU Art. 82(3), 83(3), 86(1), 87(3).

35 F. Priollaud, D. Siritzky, Le traité de Lisbonne, Texte et Commentaire, article par article des nouveaux traités européens (TUE et TFEU), La documentation Française, Paris 2008, 107.

36 E. Herlin-Karnell, "Enhanced cooperation and conflicting values: are new forms of governance the same as 'good governance'?", The Treaty of Lisbon and the future of 
Enhanced cooperation was also provided for under both Amsterdam Treaty and the Treaty of Nice, but only in the form of the default procedure, conditioned upon the Commission's willingness to forward the proposal. The mechanism was not applied under those treaties. Its first application was under the Lisbon Treaty, in 2010, and concerned divorce and legal separation. ${ }^{37}$ By 2013, there were only three cases of enhanced cooperation - in addition to the one from 2010, the second was resorted to for the purpose of creating unitary patent protection, ${ }^{38}$ whereas in 2013 Council established the financial transaction tax (FTT) as a form of enhanced cooperation. ${ }^{39}$ Blanke seems to justify the flexibility afforded to enhanced cooperation in the areas of criminal law and CFSP by the necessity that the Union provides palpable protection to its citizens, and to act upon important international developments, respectively. ${ }^{40}$

Enhanced cooperation is not the only aspect of asymmetry within the EU construct - one may not need look further than some major achievements such as the Schengen Area, the EMU, and the Fiscal Compact. Some authors regard it as a promising tool for energizing the development of EU law and for overcoming transitory difficulties, but fears that it may lead to disintegration rather than to further integration persist. ${ }^{41}$ In the context of the EU constitutional setup, therefore, enhanced cooperation remains a tool of resort to be applied for overcoming legislative and institutional impasses, strictly on temporary bases.

\section{THE EUROPEAN PUBLIC ORDER}

Judicial cooperation in criminal matters and police cooperation operate within the realm limited by the proclamations of TEU Art. 4(2), which impose upon EU the obligation to respect the maintenance of law and order as an essential function of Member States, as well as national

European Law and Policy (eds. Martin Trybus, Luca Rubini), Edward Elgar, Cheltenham - Northampton 2012, 154-155.

37 Council Decision 2010/405/EU, implemented by Council Regulation (EU) No. 1259/2010 of 20 December 2010, O.J.L. 189/12 (2010).

38 Council Decision 2011/167/EU authorising enhanced cooperation in the area of the creation of unitary patent protection, O.J. L. 76/53 (2011).

39 Council Decision 2013/52/EU authorising enhanced cooperation in the area of financial transaction tax, O.J. L. 22/11 (2013).

40 H. Blanke, "Enhanced cooperation", The Treaty on the European Union (TEU) - A Commentary, Springer Verlag, Berlin - Heidelberg 2013, 819-822.

41 C. Cantore, "We're one, but we're not the same: Enhanced Cooperation and the Tension between Unity and Asymmetry in the EU", Perspectives on Federalism 3/2011, E1-E21; Paul Craig, "Enhanced Cooperation, Amendment, and Conclusion", The Lisbon Treaty. Law, Politics, and Treaty Reform, Oxford University Press, Oxford 2010, 449. 
security as exclusive responsibility of Member States. ${ }^{42}$ Chalmers, Davies and Monti have pointed out that the wide recognition of the "EU criminal law", especially by the CJEU, seems to contravene the seemingly narrow space provided for it by TEU Art. 4(2), and have proposed two possible rationales of "EU criminal law" on which such recognition may be based: augmentation of national security of each Member State, and the operation of the European public order. ${ }^{43}$ While the former does not seem capable of either explaining the constantly growing body of supranational competences, or complying with the principle of solidarity, the latter seems to be more promising in all those respects.

While the concept of public order easily escapes exact definition, ${ }^{44}$ the common denominator of its possible meanings may be conceived to include principal elements: fundamental values of a political community, and norms necessary for the preservation of integrity and security of that community.

\section{CONCLUSION: WHAT EFFECT ON UNITY OF THE EU SHOULD BE EXPECTED FROM JUDICIAL COOPERATION IN CRIMINAL MATTERS AND POLICE COOPERATION AT EU LEVEL?}

The Lisbon Treaty transformed the nature of European legislation in the area of criminal law from intergovernmental to supranational, although important intergovernmental elements have been preserved. The principle of mutual recognition prevailed over the principle of inter-governmental coordination. The same treaty introduced direct harmonization in the subject area.

The Lisbon Treaty afforded judicial cooperation in criminal matters and police cooperation a pronounced idiosyncrasy over all other areas of EU law: a much greater degree of flexibility in relation to Member State participation. The Member States share legislative initiative with the

42 The same provision imposes upon the EU obligation to respect national identities of the Member States. Chalmers, Davies and Monti pointed out to the fact that not only "national security" has several meanings, but also that the German Constitutional Court attributed to German criminal law a significance for the German national identity, contributing to the strength of the requirement for strict interpretation of EU competences in the field of criminal law. D. Chalmers, G. Davies, G. Monti, 627-628.

43 These authors pointed out to the opinion of Advocate General Bot in Josemans case, as well as to a Commission Communication on EU Criminal Justice Policy, as sources of the doctrine on the European public order, but at the same time expressed concerns that the subject notion may serve as source for excessive criminalization and Government overreach. Ibid., 631-632.

44 See: R. de Lange, "The European public order, constitutional principles and fundamental rights", Erasmus Law Review 1/2007, 3-24. 
Commission, and the Commission may not provoke the requirement of unanimity of the Council in respect of a proposal filed by the Member States. The so-called "emergency brake" mechanism has been afforded to individual Member States exclusively in respect of proposals aimed at harmonization of substantive Union criminal law. The emergency brake is counter-balanced with the automatic enhanced cooperation of at least nine Member States, which is unfettered from Council, European Parliament and Commission approvals. In contrast to the emergency brake, automatic enhanced cooperation is available in all major aspects of legislative activity within the area of judicial cooperation in criminal matters and police cooperation. Finally, the United Kingdom was granted an option to exercise a block opt-out from the area of police cooperation and criminal law, which it did in 2013.

Pronounced institutional flexibility, peculiar to the subject area of EU law, may lead to the conclusion that it has the potential to reverse the decades-long process of EU integration, by commencing the fragmentation of the law of the European political community. ${ }^{45}$ Some authors regard the flexibility of EU law in this area as part of the larger phenomenon of the "variable geometry" of the EU, together, for example, with the European Monetary Union and the Fiscal Compact.

It seems, however, that the risk of fragmentation may seem probable only from a synchronic perspective. If the passage of time and the relevant legislative developments are taken into consideration, then a contrary conclusion appears plausible.

It should be noted that even the common variety of enhanced cooperation has been rarely used so far. Both the intended principal purpose of enhanced cooperation, and its effect in few situations it has been applied so far, was the unclogging of a stalled legislative process in relation to controversial issues, as well as overall dynamization of the legislative process. Enhanced cooperation may be regarded as an instrument for preserving the legitimacy and authority of the EU, since it enables the Member States to act in crucial situations in spite of opposition of one or more Member States. All these aspects suggest that enhanced cooperation is a tool instrumental for promoting greater unity among Member States.

Secondly, legal jurisprudence seems to suggest that this area of EU law has developed to such an extent, so that together with the EU Charter it forms part of an effective public order. On the legislative plane, TFEU Article 83(2) authorizes the EU to enact criminal law norms whenever

45 On fears of fragmentation of EU law, instigated by developments in other areas thereof, see: Branko Rakić, "Fragmentacija međunarodnog prava i evropsko pravo - na Zapadu nešto novo", Anali Pravnog fakulteta u Beogradu 1/2009, 122-147; B. Rakić, "Evropski sud pravde između ljudskih prava i brobe protiv terorizma - odnos međunarodnog i evropskog prava”, Anali Pravnog fakulteta u Beogradu 2/2009, 155-185. 
such norms prove necessary for supporting harmonization in other areas. The synergy of the greater flexibility afforded to EU law in the areas of judicial cooperation in criminal matters and police cooperation and the concept of the European public order should enable EU criminal law to continue strengthening the Union.

EU law in the subject area operates under a significant constraint - it must not infringe upon exclusive competence of Member States for protection of national security. This constraint may significantly be eased by the concept of the European public order. References to the European public order as the rationale for the persistent expansion of judicial cooperation in criminal matters and police cooperation suggest that the security and constitutional values of the EU may prevail over security and constitutional values of any Member State.

The experience gained in applying the mechanism of enhanced cooperation so far, in conjunction with the concept of the European public order, increases the utility of judicial cooperation in criminal matters and police cooperation as the new unifying factor of the EU, despite its pronounced flexibility.

\section{REFERENCES}

Blanke, H.-J. "Enhanced cooperation", The Treaty on the European Union (TEU) - A Commentary (eds. H.-J. Blanke, S. Maniameli), Springer Verlag, Berlin - Heidelberg 2013.

Brkan, M., "The Role of the European Court of Justice from Maastricht to Lisbon: Putting together the scattered pieces of patchwork", The Treaty on European Union 1993-2013: Reflections from Maastricht (eds. M. de Visser, A. Pieter van der Mei), Intersentia, Cambridge-Antwerp-Portland 2013.

Bogensberg, W., Troosters, R., "The End of Soft Law Cooperation: the Court's Jurisprudence in Criminal Matters", International Review of Penal Law 1/2006.

Cantore, C. M., "We're one, but we're not the same: Enhanced Cooperation and the Tension between Unity and Asymmetry in the EU", Perspectives on Federalism 3/2011.

Cappelletti, M., Seccombe, M., Weiler, J. H., (eds.) Integration Through Law - Europe and the American Federal Experience, Walter de Gruyter, Berlin - New York 1986.

Chalmers, D., Davies, G., Monti, G., "EU Criminal Law", European Union Law, Cambridge University Press, Cambridge $2015^{3}$. 
Craig, P., "Enhanced Cooperation, Amendment, and Conclusion", The Lisbon Treaty. Law, Politics, and Treaty Reform, Oxford University Press, Oxford 2010.

Cremona, M., "Enhanced cooperation and the common foreign and security and defense policies of the EU", EUI Working Papers, Law $21 / 2009$.

Dane, M., Goudappel, F., "European Criminal Law", Freedom, Security and Justice after Lisbon and Stockholm (eds. S. Wolff, F. Goudappel, J. de Zwaan), TMC Asser Press, The Hague 2011.

De Capitani, E., "Metamorphosis of the third pillar: The end of the transition period for EU criminal and policing law", EU Law Analysis 2014.

De Lange, R., "The European public order, constitutional principles and fundamental rights", Erasmus Law Review 1/2007.

De Witte, B., "Five Years After the Lisbon Treaty's Entry into Force: Variable Geometry Running Wild?", Editorial, Maastricht Journal of European and Comparative Law 1/2015.

Herlin-Karnell, E., "Enhanced cooperation and conflicting values: are new forms of governance the same as 'good governance'?", The Treaty of Lisbon and the future of European Law and Policy (eds. M. Trybus, L. Rubini), Edward Elgar, Cheltenham - Northampton 2012.

Klimek, L., European Arrest Warrant, Springer, Cham - Heidelberg 2015.

Klip, A., European Criminal Law: An Integrative Approach, Itersentia, Cambridge - Antwerp 2012 .

Klip, A., "Towards a General Part of Criminal Law for the European Union", Substantive Criminal Law of the European Union (ed. A. Klip), Maklu, Antwerpen - Apeldoorn 2011.

Marković, I., "Evropsko krivično pravo", Pravni život 12/2012.

Peers, S., "Childhood's End: EU Criminal Law in 2014", EU Law Analysis, http://eulawanalysis.blogspot.com/2014/12/childhoods-endeu-criminal-law-in-2014.html, last visited 15 October 2015.

Peers, S., "EU Zombie Law: the CJEU re-animates the old "third pillar", EU Law Analysis, http://eulawanalysis.blogspot.com/2015/04/euzombie-law-cjeu-re-animates-old.html, last visited 15 October 2015.

Priollaud, F.-X., Siritzky, D., Le traité de Lisbonne, Texte et Commentaire, article par article des nouveaux traités européens (TUE et TFEU), La documentation Française, Paris 2008.

Rakić, B., "Fragmentacija međunarodnog prava i evropsko pravo - na Zapadu nešto novo", Anali Pravnog fakulteta u Beogradu 1/2009. 
Rakić, B., "Evropski sud pravde između ljudskih prava i brobe protiv terorizma - odnos međunarodnog i evropskog prava", Anali Pravnog fakulteta u Beogradu 2/2009.

Vervaele, J., "Guest Editorial", Eucrim 2/2014.

Article history:

Received: 16. 11. 2015.

Accepted: 28. 11. 2016. 